\title{
Penentuan Konstanta Laju Pengeringan Coconut Chips
}

\section{Determining the Constant Drying Rate ff Coconut Chips}

\author{
Hary Kurniawan*, Sukmawaty, Ansar, Kurniawan Yuniarto, Murad, Rahmat Sabani \\ Program Studi Teknik Pertanian \\ Fakultas Teknologi Pangan dan Agroindustri, Universitas Mataram \\ *corresponding author, email: harykurniawan@unram.ac.id
}

Manuscript received: 31-12-2020. Accepted: 22-03-2021

\begin{abstract}
ABSTRAK
Penelitian ini bertujuan untuk menentukan konstanta laju pengeringan coconut chips yang dikeringkan menggunakan oven. Pengeringan coconut chips dilakukan pada suhu pengeringan $50^{\circ} \mathrm{C}$, $60^{\circ} \mathrm{C}$ dan $70^{\circ} \mathrm{C}$. Pengeringan coconut chips dilakukan pada kadar air awal 40-50\% wb hingga mencapai $\pm 10 \%$ wb. Perubahan kadar air bahan diukur setiap 15 menit dan pengukuran kadar air ditentukan dengan cara termogravimetri. Model Newton digunakan dalam penentuan konstanta laju pengeringan observasi. Selanjutnya konstanta laju pengeringan observasi digunakan untuk memprediksi konstanta laju pengeringan sebagai fungsi suhu menggunakan persamaan Arrhenius. Hasil penelitian menunjukkan nilai konstanta laju pengeringan prediksi berkisar antara 0.0090 0.0130 menit $^{-1}$.
\end{abstract}

Kata kunci : coconut chips; konstanta laju pengeringan; pengeringan

\begin{abstract}
This study aims to determine the drying rate constant of coconut chips using an oven. Coconut chips drying is carried out at drying temperatures of $50^{\circ} \mathrm{C}, 60^{\circ} \mathrm{C}$ and $70{ }^{\circ} \mathrm{C}$. Drying coconut chips has been conducted at an initial water content of $40-50 \%$ wb until it reached $\pm 10 \% \mathrm{wb}$. The change of moisture content was measured every 15 minutes, and the measurement of the water content was determined by the thermogravimetric method. Newton's model was used in determining the observation drying rate constant. Furthermore, the observation drying rate constant was applied to predict the drying rate constant as a function of temperature using the Arrhenius equation. The results showed that the predicted drying rate constants ranged from $0.0090-0.0130$ minute $^{-1}$.
\end{abstract}

Keywords: coconut chips; drying rate constant; drying

\section{PENDAHULUAN}

Daging buah kelapa telah lama dimanfaatkan sebagai bahan baku berbagai produk pangan karena mempunyai komposisi yang sangat baik bagi kesehatan. Komposisi kimia daging buah kelapa antara lain kadar air 49 - 51\%, kadar lemak 52,95-57,78\%, protein 8,14 
- 8,74\%, karbohidrat $12,68-14,14 \%$ dan serat kasar 3,78 - 7,40\%. Selain itu kandungan kalori buah kelapa tua diketahui cukup tinggi yaitu sebesar 354 kal dalam 100 gramnya. Selain lemak, daging buah kelapa juga mengandung protein, karbohidrat, serat, vitamin dan mineral. Hal ini membuktikan bahwa, daging kelapa dapat digunakan sebagai sumber nutrisi bahan pangan (Agustina et al., 2020; Subagio, 2020; Barlina, 2007). Sebagai sumber protein, daging kelapa sangat baik karena tidak mengandung senyawa antinutrisi, sementara apabila sebagai bahan baku minyak goreng, juga tergolong sangat baik karena mengandung lebih 90\% asam lemak jenuh, sehingga tahan oksidasi. Sedangkan sebagai pemasok asam lemak rantai medium, terutama asam laurat yang dapat mencapai lebih dari 50\%, tubuh akan memperoleh kalori yang lebih cepat dibanding lemak nabati lainnya (Barlina, 2007).

Daging buah kelapa merupakan komponen yang paling banyak dimanfaatkan untuk produk pangan maupun nonpangan. Daging kelapa dapat diolah menjadi berbagai produk seperti VCO (Subagio, 2020; Barlina, 2007), santan (Kumolontang, 2015; Karouw \& Santosa, 2018), desiccated coconut (Kurniawan et al., 2020), untuk bahan baku makanan semi padat seperti koktil, selai, tart kelapa dan suplemen makanan bayi (Barlina, 2004), bahan baku minyak goreng (Barlina, 2007).

Keripik kelapa (coconut chips) merupakan produk yang terbuat dari daging buah kelapa yang, berwarna putih, renyah dan manis serta mempunyai bau khas kelapa. Pada umumnya, buah kelapa yang digunakan untuk pembuatan olahan kripik ini adalah buah kelapa yang berumur 7-8 bulan. Olahan kripik dari buah kelapa ini bisa dikonsumsi sebagai makanan ringan atau makanan yang dikeringkan (Rizky \& Mavianti, 2019; Agustina et al., 2020). Keripik kelapa dapat menjadi salah satu alternatif bagi masyarakat sebagai produk camilan yang memiliki nilai gizi yang tinggi serta menjadi salah satu alternatif peluang usaha sehingga terciptanya lapangan pekerjaan baru (Rizky \& Mavianti, 2019). Salah satu tahapan dalam pembuatan keripik kelapa yaitu pengeringan. Pengeringan dilakukan untuk mengurangi sebagian besar air yang terdapat dalam bahan agar bahan menjadi lebih awet selama penyimpanan (Pamungkas et al., 2008; Syaiful \& Hargono, 2009).

Salah satu faktor yang menentukan cepat lambatnya massa air untuk meninggalkan bahan selama proses pengeringan yaitu konstanta laju pengeringan. Konstanta laju pengeringan, yang disimbolkan dengan $\mathrm{k}$, merupakan besaran yang menyatakan tingkat kecepatan air atau massa air untuk berdifusi keluar meninggalkan bahan yang dikeringkan. Kajian mengenai penentuan konstanta laju pengeringan telah banyak dilakukan. Perubahan konstanta laju pengeringan pasta telah diinvestigasi dengan pemberian perlakuan awal berupa puffing udara untuk memperbesar pori-pori dari pasta (Pamungkas et al., 2008). Selain itu, nilai konstanta laju pengeringan jagung selama pengeringan dengan metode penjemuran dan menggunakan pengering rumah kaca telah dipelajari oleh Apriadi et al. (2011). Investigasi laju pengeringan chips mocaf menggunakan cabinet dyer dimana diperoleh temperature optimal dan kosntanta laju pengeringan puncak terjadi pada suhu $70^{\circ} \mathrm{C}$ juga telah dilaporkan Sushanti \& Sirwanti (2018). Penentuan konstanta laju pengeringan pada kelapa parut (desiccated coconut) menggunakan pengering tipe rak berbentuk silinder telah dilaorkan oleh Kurniawan et al. (2020). Konstanta laju pengeringan pada bawang merah iris pada berbagai 
variasi suhu pengeringan menggunakan tunnel dehydrator juga telah dilaporkan Ummah et al. (2016). Konstanta laju pengeringan dari hubungan debit udara dan penurunan kadar air pada periode laju konstan serta konstanta laju pengeringan dari hubungan perubahan kadar air dan siklus selama pengeringan kelapa parut kering secara pneumatic telah diinvestigasi (Nugraha et al., 2012). Dilaporkan bahwa penurunan kadar air terhadap debit dan suhu udara, dan perubahan kadar air terhadap siklus digunakan untuk menentukan nilai konstanta laju pengeringan(k), energi aktivasi (Ea) dan faktor frekuensi tumbukan(A). Penurunan kadar air terhadap variasi pemberian bisulfit dan suhu udara digunakan untuk menentukan nilai konstanta laju pengeringan (k), energi aktivasi (Ea) dan faktor frekuensi tumbukan (A) juga telah dilaporkan oleh Putri \& Karyadi (2014). Selain itu juga diinvetigasi konstanta laju pengeringan dari hubungan suhu pengering dan penurunan kadar air pada periode laju konstan dan menurun. Sebuah persamaan empiris diajukan oleh Rahayu et al. (2008) dalam menentukan konstanta laju pengeringan pada pengeringan daun sambiloto menggunakan pengering tekanan rendah. Persamaan empiris untuk memprediksi konstanta laju pengeringan duan sambiloto tersebut tersebut merupakan fungsi suhu dan tekanan. Selain itu dilaporkan pula bahwa pengeringan menggunakan tekanan rendah dapat meningkatkan laju pengeringan.

Berdasarkan studi literatur, kajian mengenai penentuan konstanta laju pengeringan pada keripik kelapa masih belum tersedia, oleh karena itu penelitian ini bertujuan untuk mempelajari penentuan kontanta laju pengeringan keripik kelapa (coconut chips) selama pengeringan menggunakan oven pada berbagai variasi suhu pengeringan.

\section{BAHAN DAN METODE}

\section{Alat dan Bahan}

Bahan yang digunakan adalah kelapa yang diperoleh di pasar tradisional di kota Mataram. Sementara itu peralatan yang digunakan yaitu termodigital tipe K (Xintest HT9815, China), oven (Memmert UNB 400), moisure analyzer (BMO35, Boeco, Germany), timbangan analitik (Kern ABJ 220, Germany), cawan, desikator, loyang, slicer, dan penjepit

\section{Tahapan Penelitian}

\section{Persiapan Bahan Baku}

Sampel yang digunakan dalam penelitian ini adalah kelapa. Kelapa yang telah diambil daging buahnya mula-mula dibersihkan dari kulit arinya, lalu dicuci bersih dan ditiriskan.

Setelah itu daging kelapa diiris tipis menggunakan slicer. Irisan daging kelapa memilik ketebalan $\pm 1 \mathrm{~mm}$.

\section{Pengukuran Kadar Air Awal}

Sampel (daging kelapa yang telah diiris) ditimbang sebanyak $2 \mathrm{~g}$ dalam cawan moisture analyzer dan diset pada suhu $105{ }^{\circ} \mathrm{C}$, setelah itu ditutup dan ditunggu hasil kadar airnya. Hasil kadar air dicatat. 


\section{Pengeringan}

Sebanyak 300 gram daging kelapa yang telah di iris tipis, diletakkan pada loyang dan pastikan sampel tidak saling bertumpuk. Kemudian atur suhu pada alat pengering yang telah ditentukan. Pada penelitian ini variasi suhu pengeringan yaitu 50, 60 dan $70^{\circ} \mathrm{C}$. Pada ruang pengeringan di pasang kabel termokopel pada masing-masing rak. Pada 1 jam pertama suhu udara di dalam ruang pengering dipantau setiap 1 menit, lalu dilanjutkan setiap 5 menit. Sementara setiap 5 menit rak berisi sampel ditimbang untuk mengetahui perubahan kadar air bahan selama pengeringan. Pengeringan dianggap selesai apabila telah tercapai bobot konstan.

\section{Pemodelan Matematika}

Salah satu model pengeringan yang paling sederhana dan banyak digunakan adalah model pengeringan lapis tipis yaitu (Rahman et al., 2015; Borah et al., 2015):

$$
\frac{d M}{d t}=-k\left(M-M_{e}\right)
$$

Persamaan ini kemudian diselesaikan dengan integrasi analitik sehingga diperoleh persamaan:

$$
\begin{gathered}
\frac{M-M_{e}}{M_{o}-M_{e}}=\exp (-k t) \\
M R=\exp (-k t) \ldots \ldots
\end{gathered}
$$

Nilai $\frac{M-M_{e}}{M_{o}-M_{e}}$ disebut nisbah lengas atau Moisture Ratio (MR), dimana M merupakan kadar air bahan pada lama pengeringan t menit, Mo merupakan kadar air awal bahan dan Me adalah kadar air setimbang bahan pada saat proses pengeringan. Selanjutnya persamaan 3 dilinierkan sehingga menjadi :

$$
\operatorname{Ln}\left(\frac{M-M_{e}}{M_{o}-M_{e}}\right)=-k t
$$

Kemudian dibuat grafik hubungan $\ln \operatorname{Ln}\left(\frac{M-M_{e}}{M_{o}-M_{e}}\right)$ sebagai sumbu Y versus waktu (t) sebagai sumbu $\mathrm{X}$, yang akan menghasilkan persamaan linier berbentuk $\mathrm{y}=\mathrm{b}$ x. Nilai slope (b) merupakan nilai konstanta laju pengeringan bahan. Nilai k kemudian dicari pada berbagai variasi suhu dengan cara yang sama.

Selanjutnya nilai konstanta laju pengeringan di prediksi menggunakan persamaan Arhenius seperti berikut (Peleg et al., 2012):

$$
k=k_{o} e^{\frac{E_{a}}{R} \frac{1}{T}}
$$

Persamaan di atas selanjutnya di linierkan mejadi:

$$
\ln k=\ln k_{o}+\frac{E_{a}}{R} \cdot \frac{1}{T}
$$

Untuk menentukan kadar air prediksi maka persamaan (2) diubah menjadi :

$$
M=\left[\exp (-k t) \cdot\left(M_{o}-M_{e}\right)\right]+M_{e} \ldots(7)
$$

Setelah diperoleh nilai konstanta laju pengeringan prediksi pada setiap variasi suhu pengeringan, maka kadar air bahan dapat diprediksi menggunakan persamaan 7 dengan mensubstitusikan nilai $\mathrm{k}$. 


\section{Perubahan Kadar Air Selama Pengeringan}

\section{HASIL DAN PEMBAHASAN}

Gambar 1 menunjukkan perubahan kadar air bahan selama pengeringan. Berdasarkan hasil pengukuran, kadar air awal rata-rata bahan sebesar 47,52\% wb. Selama pengeringan menunjukkan bahwa kadar air bahan mengalami penurunan pada setiap perlakukan suhu pengeringan. Sejumlah air dari bahan meninggalkan bahan akibat adanya perbedaan tekanan antara bahan dan lingkungan serta $\mathrm{RH}$ yang rendah di ruang pengering. Pada variasi suhu pengeringan 50 dan $60^{\circ} \mathrm{C}$, penurunan kadar air terjadi cukup cepat diawal pengeringan terutama pada 300 menit pertama yang ditandai dengan kemiringan garis grafik. Setelah itu, garis kuva cederung melandai dan penurunan perubahan kadar air relative kecil. Hal yang sama juga terjadi pada variasi suhu pengeringan $70^{\circ} \mathrm{C}$, dimana penurunan perubahan kadar air terjadi secara dramatis pada 100 memnit pertama, setelah itu penurunan perubahan kadar air cenderung kecil yang ditandai garis kurva yang melandai. Pada awal proses pengeringan, kandungan air bebas yang terdapat dalam bahan masih tinggi dan mudah dilepaskan sedangkan pada akhir pengeringan kandungan air sudah mulai sulit dilepaskan karena kadar air bahan terikat. Tekanan uap air dari air terikat akan lebih rendah dibandingkan tekanan uap air bebas pada suhuyang sama (Ummah et al., 2016). Hasil menunjukkan bahwa semakin tinggi suhu pengeringan, maka durasi pengeringan juga semakin cepat, terutama terjadi pada suhu $70^{\circ} \mathrm{C}$ yang berlangsung dalam 420 menit atau 7 jam.

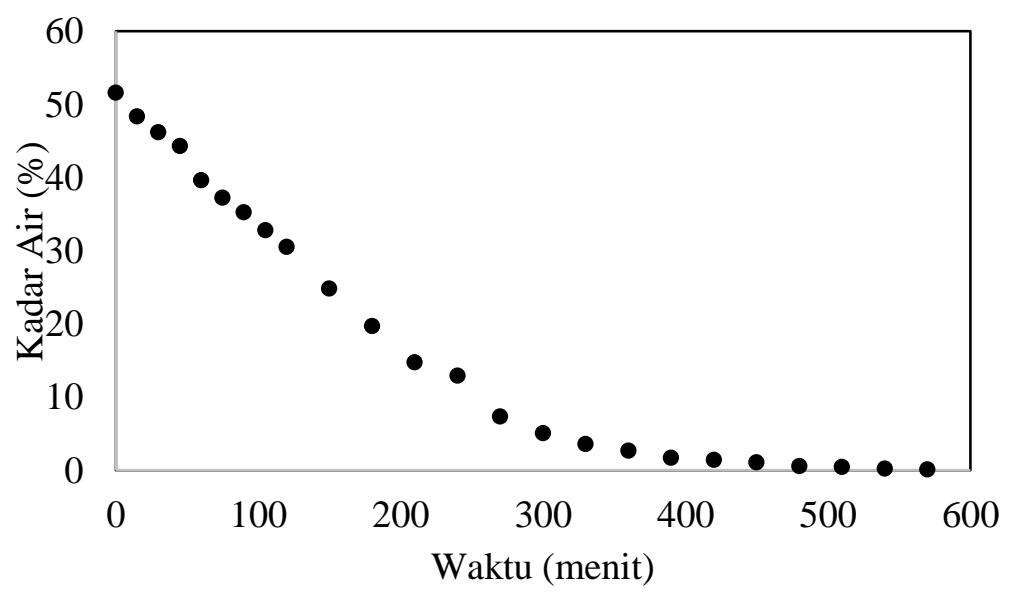

(a) 


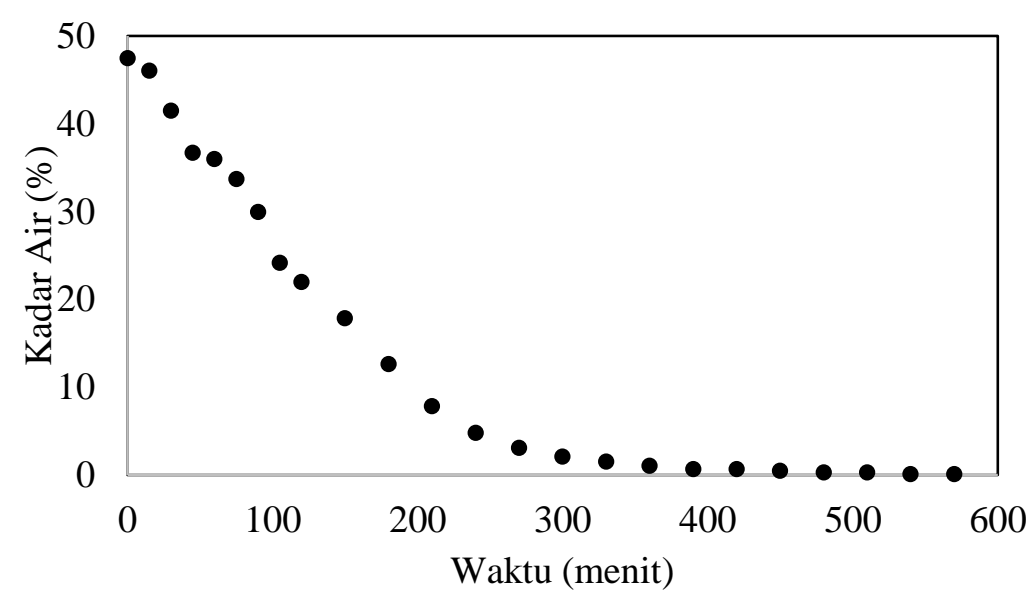

(b)

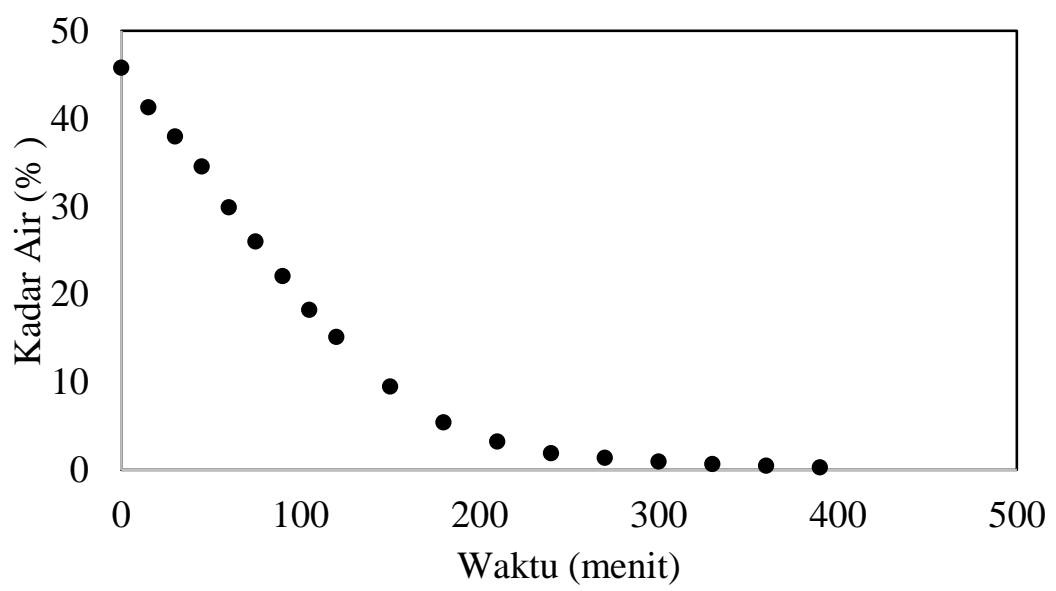

(c)

Gambar 1. Perubahan kadar air bahan selama pengeringan: (a) $50^{\circ} \mathrm{C}$, (b) $60^{\circ} \mathrm{C}$ dan (c) $70^{\circ} \mathrm{C}$

\section{Konstanta Laju Pengeringan}

Konstanta laju pengeringan $(\mathrm{k})$ merupakan sebuah besaran digunakan sebagai indikator seberapa cepat proses pengeringan berlangsung pada suatu bahan. Nilai konstanta laju pengeringan sangat tergantung pada besarnya harga koefisien difusi suatu bahan yang dikeringkan, dimana keduanya berbanding lurus (Pamungkas et al., 2008; Ummah et al., 2016; Rahayoe et al., 2008).

Penentuan konstanta laju pengeringan keripik kelapa ditentukan melalui grafik hubungan antara Ln (M-Me/Mo-Me) terhadap waktu seperti ditunjukkan Gambar 2, sehingga diperoleh garis grafik dengan persamaan $\mathrm{y}=\mathrm{b}$. Nilai $\mathrm{b}$ adalah kemiringan atau slope persamaan garis kurva yang menunjukkan nilai konstanta laju pengeringan observasi seperti yang ditunjukkan pada Tabel 1. 


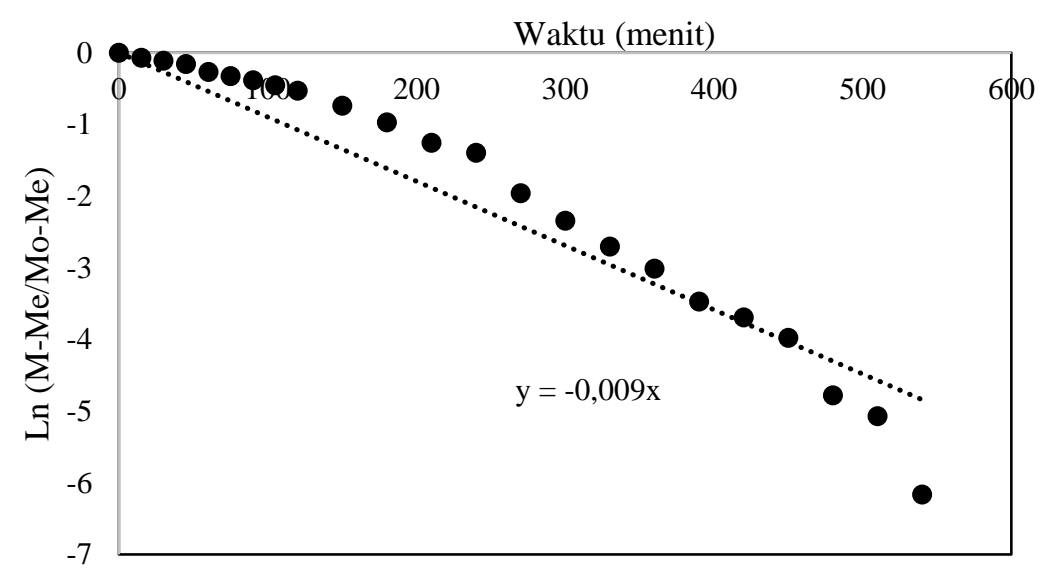

(a)

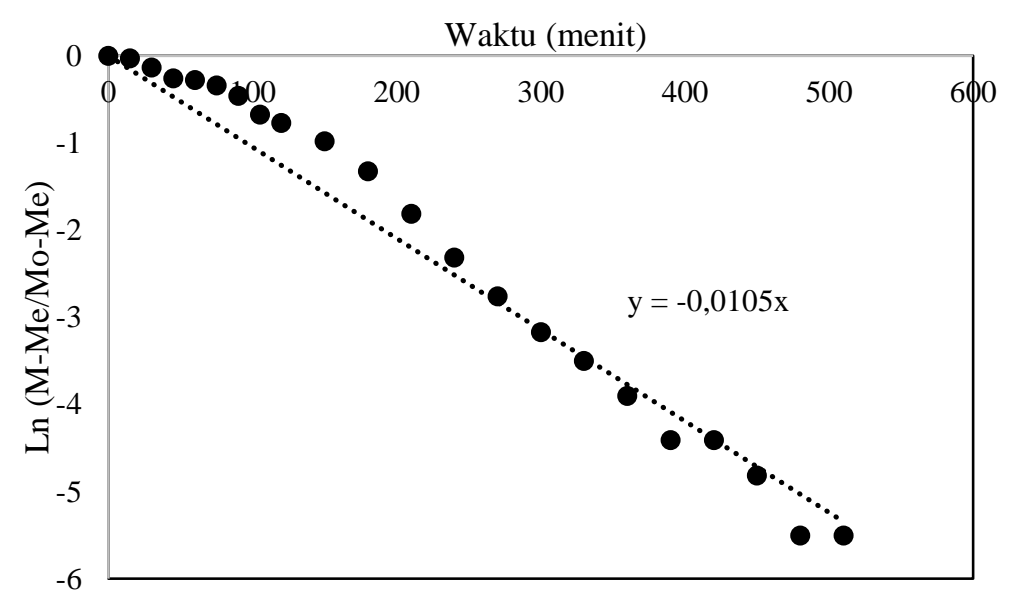

(b)

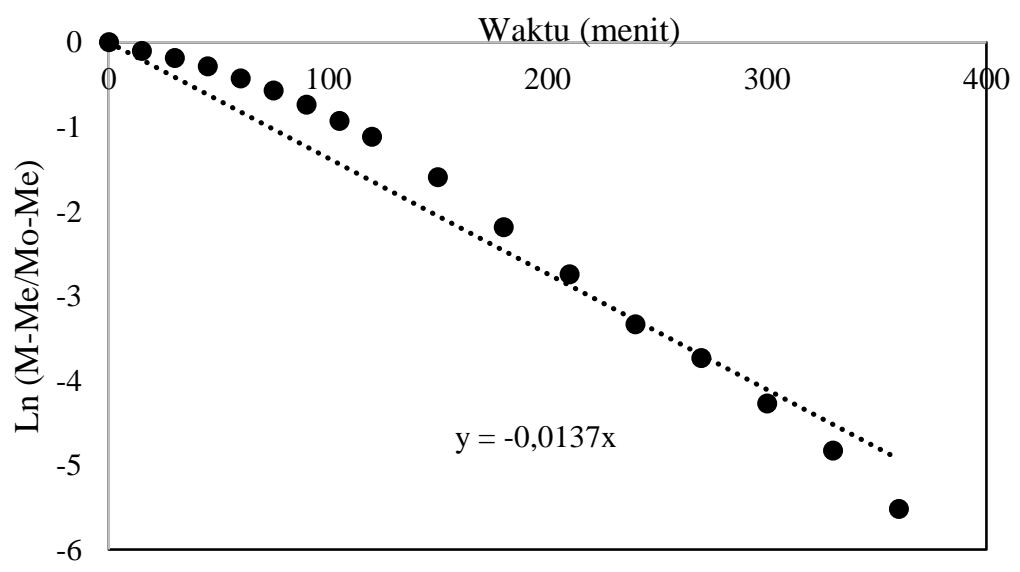

(c)

Gambar 2. Grafik Ln (M-Me/Mo-Me) vs waktu (t) pada suhu : (a) $50^{\circ} \mathrm{C}$, (b) $60^{\circ} \mathrm{C}$ dan (c) $70^{\circ} \mathrm{C}$ 
Tabel 1. Konstanta laju pengeringan observasi $\left(\mathrm{k}_{\mathrm{obs}}\right)$ coconut chips pada berbagai variasi suhu pengeringan

\begin{tabular}{cc}
\hline Suhu $\left({ }^{\mathbf{0}} \mathbf{C}\right)$ & Konstanta Laju Pengeringan Observasi $\left(\right.$ Kobs $\left._{\text { menit }}{ }^{-\mathbf{1}}\right)$ \\
\hline $\mathbf{5 0}$ & 0,0090 \\
$\mathbf{6 0}$ & 0,0105 \\
$\mathbf{7 0}$ & 0,0137 \\
\hline
\end{tabular}

Nilai konstanta laju pengeringan observasi $\left(\mathrm{k}_{\mathrm{obs}}\right)$ selanjutnya digunakan untuk untuk menentukan nilai konstanta laju pengeringan prediksi ( $\mathrm{k}_{\text {pred}}$ ) sebagai fungsi suhu $(\mathrm{T})$ melalui persamaan (5) dan diperoleh persamaan kontanta laju pengeringan prediksi sebagai berikut:

$$
k_{\text {Prediksi }}=11,6336 e^{\frac{-19293,4684}{R}} \frac{1}{T}
$$

Nilai konstana laju pengeringan prediksi yang dihitung melalui persamaan (8) ditunjukkan pada Tabel 2. Pada Gambar 3 terlihat bahwa nilai k observasi dan k prediksi memiliki trend sama secara polinomial. Nilai tersebut digambarkan dengan nilai $\mathrm{R}^{2}$ yang mendekati 1.

Tabel 2. Konstanta laju pengeringan prediksi ( $\left.\mathrm{k}_{\mathrm{pred}}\right)$ keripik kelapa pada berbagai variasi suhu pengeringan

\begin{tabular}{cc}
\hline Suhu $\left({ }^{\circ} \mathbf{C}\right)$ & Konstanta Laju Pengeringan Prediksi $\left(\mathbf{K}_{\text {pred }}\right.$ menit $\left.^{-1}\right)$ \\
\hline $\mathbf{5 0}$ & 0,009 \\
\hline $\mathbf{6 0}$ & 0,011 \\
\hline $\mathbf{7 0}$ & 0,013 \\
\hline
\end{tabular}

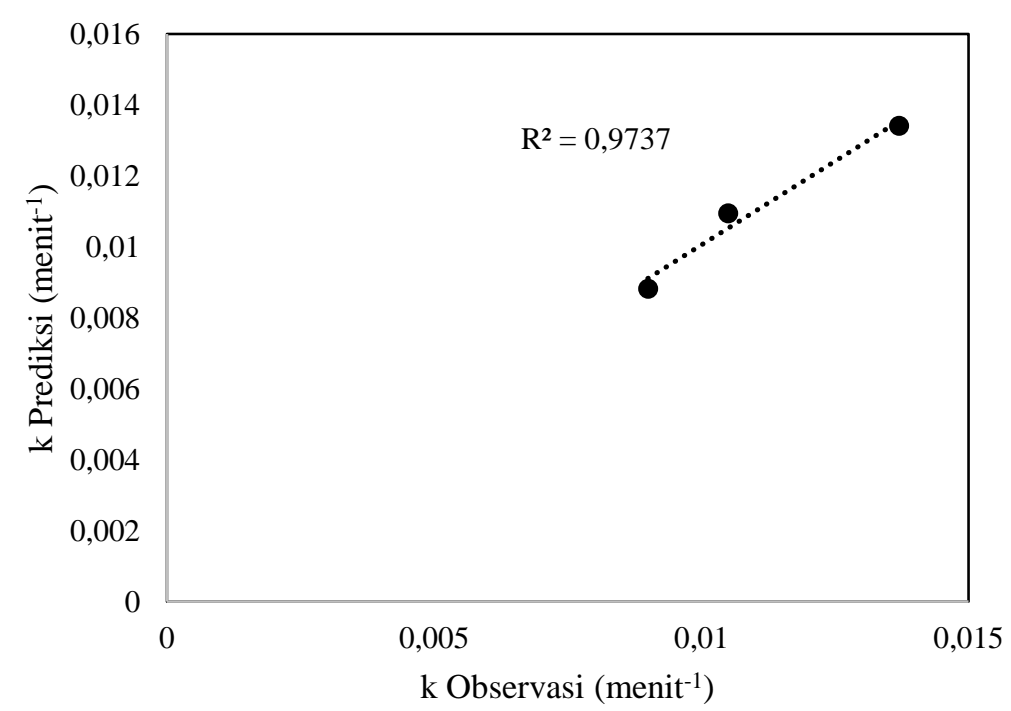

Gambar 3. Hubungan antara konstanta laju pengeringan prediksi dan konstanta laju pengeringan observasi

Nilai konstanta laju pengeringan prediksi selanjutnya digunakan untuk memprediksi kadar air pada berbagai variasi suhu pengeringan melalui persamaan (7) dengan diketahui nilai kadar air awal (Mo) dan kadar air setimbang (Me) bahan. Dengan memasukkan nilai 
konstanta laju pengeringan prediksi $\left(\mathrm{k}_{\text {pred }}\right) \mathrm{ke}$ dalam persamaan (7) maka diperoleh kadar air prediksi seperti yang ditunjukkan pada Gambar 4.

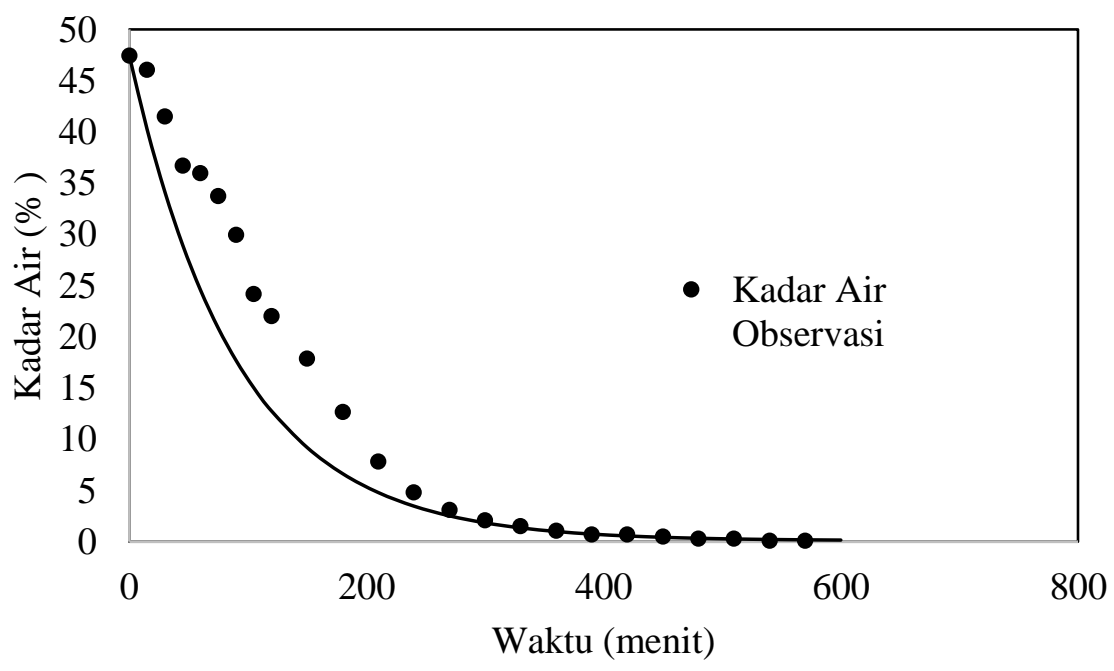

Gambar 4. Kadar air prediksi pada suhu $60^{\circ} \mathrm{C}$

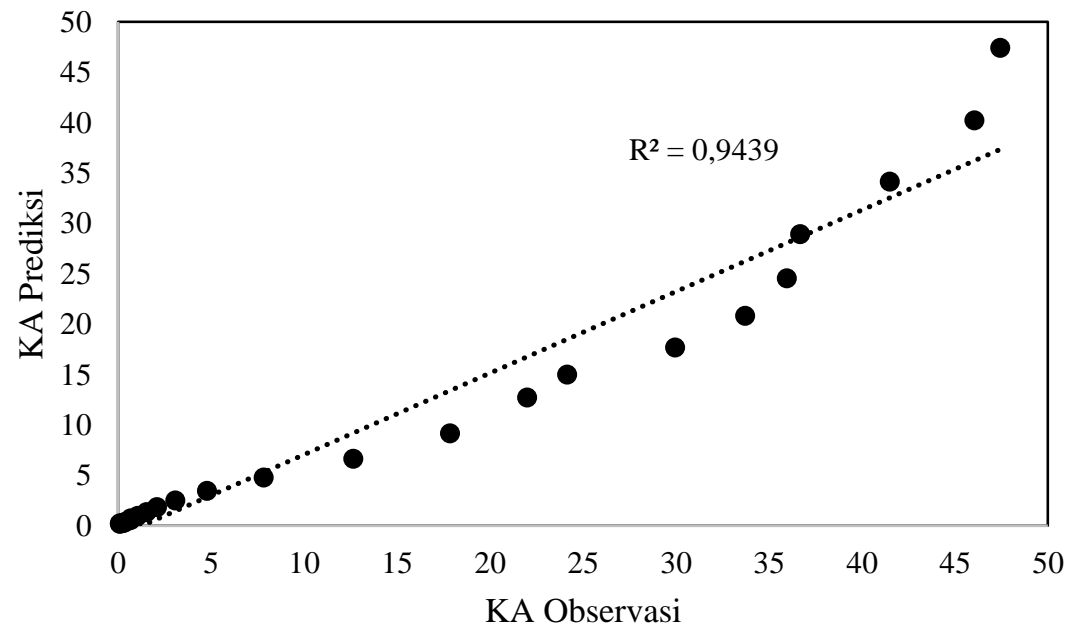

Gambar 5. Hubungan kadar air observasi dan kadar air prediksi pada suhu $60^{\circ} \mathrm{C}$

Nilai kadar air prediksi yang dihitung melaui persamaan (7) selanjutnya divalidasi melalui kurva hubungan antara kadar air observasi dan kadar air prediksi seperti yang ditunjukkan pada Gambar 5, sehingga diperoleh kurva dengan nilai koefisien determinasi $\left(\mathrm{R}^{2}\right)$. Nilai koefisien determinasi menunjukkan fit and good antara kadar air yang diprediksi menggunakan model terhadap kadar air hasil pengukuran (observasi). Berdasarkan hasil perhitungan diperoleh nilai $\mathrm{R}^{2}$ untuk suhu pengeringan 50,60 dan $70^{\circ} \mathrm{C}$ berturut-turut 0,9385 , 0,9439, dan 0,9550 yang nilainya hampir mendekati 1. Ini menunjukkan bahwa model matematis yang dibangun dapat memprediksi kadar air keripik kelapa dengan baik dan mendekati kadar air hasil pengukuran (observasi). Dengan demikian dapat dinyatakan bahwa 
model matematis konstanta laju pengeringan dapat digunakan untuk memprediksi perubahan kadar air keripik selama pengeringan.

\section{KESIMPULAN}

Hasil penelitian diperoleh model matematis pengeringan keripik kelapa (coconut chip) pada berbagai variasi suhu pengeirngan yaitu:

$$
M(\text { Kadar Air Prediksi })=\{[\exp (-k t) .0,3152]+0,1599\} \times 100
$$

dimana $\mathrm{t}$ adalah waktu pengeringan dalam menit dan $\mathrm{k}$ adalah konstanta laju pengeringan yang dapat diprediksi berdasarkan fungsi suhu yaitu:

$$
k_{\text {Prediksi }}=11,6336 e^{\frac{-19293,4684}{R} \frac{1}{T}}
$$

\section{Ucapan Terimakasih}

Tim peneliti menyampaikan terima kasih kepada LPPM Universitas Mataram atas dukungan dana penelitian melalui sumber dana PNBP Universitas Mataram Tahun Anggaran 2020

\section{DAFTAR PUSTAKA}

Agustina, Y., Septiany, P.R., Arlinda, \& Safitri, K. 2020. Pembuatan Keripik Kelapa Sebagai Upaya Pemulihan Ekonomi Pasca Bencana di Kabupaten Lombok Utara. Jurnal Karinov, 3(2), $79-83$.

Apriadi, Amanah, H. Z., \& Bintoro, N. 2011. Analisis Perpindahan Panas Dan Massa Proses Pengeringan Jagung Tongkol Pada Beberapa Metode Pengeringan Sederhana. Prosiding Seminar Nasional Perteta 2011, 21-22 Juli 2011 Jember, 319-329.

Barlina, R. 2004. Potensi Buah Kelapa Muda Untuk Kesehatan dan Pengolahannya. Perpsektif, 3(2), 46 - 60.

Barlina, R. 2007. Potensi Kelapa Sebagai Sumber Gizi Alternatif untuk Mengatasi Rawan Pangan. Buletin Palma, 32, 68 - 80.

Borah, A., Hazarika, K., \& Khayer, S.M. 2015. Drying kinetics of whole and sliced turmeric rhizomes (Curcuma longa L.) in a solar conduction dryer. Information Processing in Agriculture, 2, 85-92

Karouw, S. \& Santosa, B. 2018. Stabilitas Santan Kelapa pada Variasi Penambahan Emulsifier Natrium Kaseinat. Buletin Palma, 19 (1), 27 - 32

Kumolontang, N. 2015. Pengaruh Penggunaan Santan Kelapa dan Lama Penyimpanan Terhadap Kualitas “Cookies Santang”. Jurnal Penelitian Teknologi Industri , 7 (2), 69-79.

Kurniawan, H., Muiz, A., Mbele, M.I.F., Dini, R.O, \& Baskara, W.B. 2020. Karakteristik Pengeringan Kelapa Parut Menggunakan Alat Pengering Silinder Tipe Rak. Agrointek, 14(2), 286-294.

Nugraha, B., Karyadi, J.N.W., \& Bintoro, N. 2012. Pengaruh Laju Udara dan Suhu Selama Pengeringan Kelapa Parut Kering Secara Pneumatic. Seminar Nasional Perteta Malang, 116-128. 
Pamungkas, W.H., Bintoro, N., Rahayu, S., \& Rahardjo, B. 2008. Perubahan Konstanta Laju Pengeringan Pasta dengan Perlakuan Awal Puffing Udara. Prosiding Seminar Nasional Teknik Pertanian 2008-Yogyakarta, 18-19 November 2008, 1 - 15.

Peleg, M., Normand, M. D., \& Corradini, M. G. Corradini. 2012. The Arrhenius Equation Revisited, Critical Reviews in Food Science and Nutrition, 52:9, 830-851

Putri, Y.I. \& Karyadi, J.N.W. 2014. Analisis Pengeringan Kelapa Parut Menggunakan Kabinet Dryer dengan Variasi Suhu dan Metode Pemberian Natrium Bisulfit. Skripsi. Teknik Pertanian. FTP. UGM. Yogyakarta.

Rahayoe, S., Rahardjo, B., \& Kusumandari, Rr.S. (2008). Konstanta Laju Pengeringan Daun Sambiloto Menggunakan Pengering Tekanan Udara. Jurnal Rekayasa Proses, 2 (1), 17-23.

Rahman, S. N. F. S. A., Wahid, R., \& Rahman, N. Ab., 2015. Drying Kinetics of Nephelium Lappaceum (Rambutan) in a Drying Oven. World Conference on Technology, Innovation and Entrepreneurship, Procedia - Social and Behavioral Sciences, 195, $2734-2741$

Rizky, R.N. \& Mavianti. 2019. Keripik Kelapa : Peluang Usaha Baru di Dusun 3 Tanjung Anom, Deli Serdang Proseding Seminar Nasional Kewirausahaan : Hasil Penelitian dan Pengabdian Kepada Masyarakat, 1(1), 311-318

Subagio, A. 2020. Potensi Daging Buah Kelapa sebagai Bahan Baku Pangan Bernilai. Pangan, 20 (1), 15-26.

Sushanti, G \& Sirwanti. 2018. Laju Pengeringan Chips Mocaf Menggunakan Cabinet Dryer. Jurnal Galung Tropika, 7(3), 229-235.

Syaiful, M \& Hargono. 2009. Profil Suhu Pada Proses Pengeringan Produk Pertanian dengan Simulasi Computational Fluid Dynamics (CFD). Reaktor, 12(3), 195 - 202.

Ummah, N., Purwanto, Y.A., \& Suryani, A. (2016). Penentuan Konstanta Laju Pengeringan Bawang Merah (Allium ascalonicum L.) Iris Menggunakan Tunnel Dehydrator. Warta IHP/Journal of Agro-based Industry, Vol. 33(2), 49-56. 